\title{
Urban Mobility Symposium: Karten, Daten, Geovisualisierung
}

\author{
Sebastian Meier ${ }^{1}$ Johannes Kröger ${ }^{2}$
}

Published online: 15 April 2020

(c) The Author(s) 2020

Unsere Städte sind Schmelztiegel der Innovation und ein wichtiger Eckpfeiler auf dem Weg in eine nachhaltige Zukunft. Die Betrachtung urbaner Mobilität ist in diesem Zusammenhang von essentieller Bedeutung, ob für das Zusammenleben in einer sich wandelnden Welt oder für die Ermöglichung wirtschaftlicher Prozesse. Der traditionelle, motorisierte Verkehr ist eine wichtige Einflussgröße für Luft- und Lärmverschmutzung im urbanen Raum. Ein zunehmend diverser "Modal Split" mit neuen Formen individueller oder gemeinsam genutzter Mobilitätsmöglichkeiten stellt Verkehrsplaner*innen vor Herausforderungen. In diesem Spannungsfeld ermöglichen Analysen und Visualisierungen räumlicher Informationen den verschiedenen Akteur*innen des städtischen Raumes Einblicke in Zusammenhänge und Entwicklungen.

Im Rahmen des Urban Mobility Symposiums, welches im Oktober 2019 im CityLAB Berlin stattfand, diskutierten Forscher*innen und Anwender*innen die Chancen und Herausforderungen dabei die Stadt durch Daten, Karten und Geovisualisierungen besser zu verstehen. In dieser Sonderausgabe veröffentlichen wir einen Auszug der präsentierten Arbeiten.

Praxisnah diskutieren Anita Graser et al. aktuelle Entwicklungen der Analyse von Bewegungsdaten. Die Potentiale und Faszination solcher Mobilitätsdaten im Kontext der Visualisierungslehre werden von Till Nagel dargelegt. Eine Transekt-Analyse lokaler Daten entlang von Ausfallstraßen in Hamburg von Timotheus Klein et al. zeigt die strukturellen Unterschiede zwischen Außenbezirken und Innenstadt auf. Christoph Aberle untersucht Disparitäten der soziodemografischen Charakteristiken von Geschäftsgebieten moderner Mobilitätskonzepte in Hamburg. Auf die

Sebastian Meier

sebastian.meier@hcu-hamburg.de

1 g2lab and CityScienceLab, Hafen-City-Universität Hamburg, Hamburg, Germany

2 Geoinformatik, Hafen-City-Universität Hamburg, Hamburg, Germany
Bedürfnisse der diversen Stadtgesellschaft fokussieren sich Fabio Galicio et al. mit einem partizipativen Projekt zur Neugestaltung von Verkehrsflächen in Los Angeles. Die persönliche Wahrnehmung von Stress im mobilen Erleben städtischer Räume wird durch Heike Marquart et al. in einer Kombination qualitativer und quantitativer Verfahren erhoben.

Das Urban Mobility Symposium und die Sonderausgabe wurden gemeinsam von der Technologiestiftung Berlin, der HafenCity Universität Hamburg und der Deutschen Gesellschaft für Kartographie organisiert.
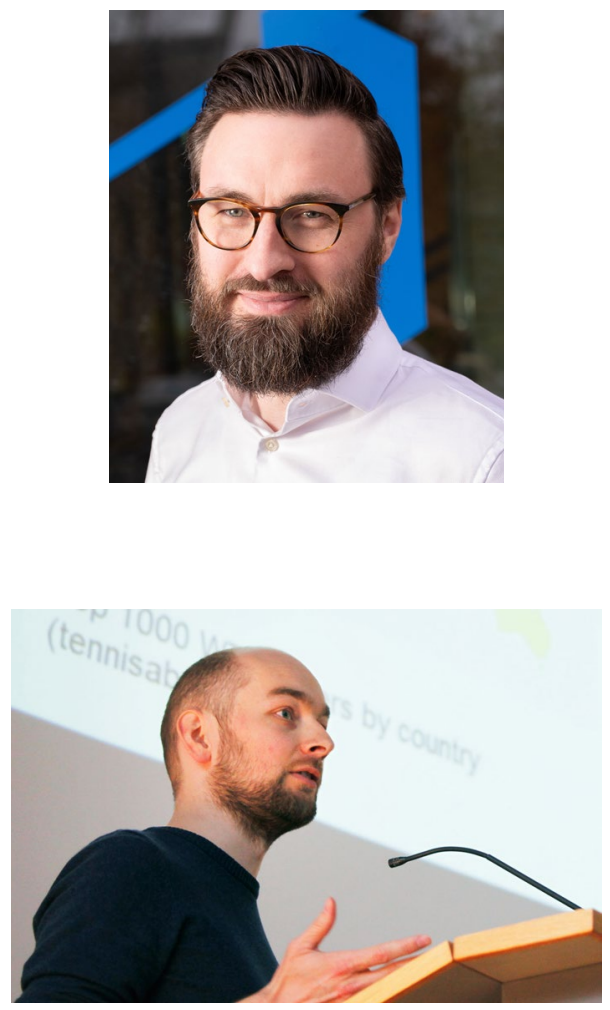

Acknowledgements Open Access funding provided by Projekt DEAL. 
Open Access This article is licensed under a Creative Commons Attribution 4.0 International License, which permits use, sharing, adaptation, distribution and reproduction in any medium or format, as long as you give appropriate credit to the original author(s) and the source, provide a link to the Creative Commons licence, and indicate if changes were made. The images or other third party material in this article are included in the article's Creative Commons licence, unless indicated otherwise in a credit line to the material. If material is not included in the article's Creative Commons licence and your intended use is not permitted by statutory regulation or exceeds the permitted use, you will need to obtain permission directly from the copyright holder. To view a copy of this licence, visit http://creativecommons.org/licenses/by/4.0/. 